Journal of Contemporary Research in Business, Economics and Finance

ISSN: 2641-0265

Vol. 1, No. 4, pp. 56-61

2019

Publisher: Learning Gate

DOI: $10.33094 / 26410265.2019 .14 .56 .61$

(C) 2019 by the authors; licensee Learning Gate

\title{
Predicting the Effects of Economic Diversification on Solid Mineral Development in Nigeria
}

\author{
Richardson Kojo Edeme \\ Department of Economics, University of Nigeria, Nsukka, Nigeria \\ Email: richard.edeme@unn.edu.ng \\ Nelson C Nkalu \\ Department of Economics, University of Nigeria, Nsukka, Nigeria \\ Email:nelson.nkalu@unn.edu.ng
}

Received: 10 September 2019; Revised: 4 October 2019; Accepted: 23 October 2019; Published: 6 November 2019

\begin{abstract}
As argued by Hlavová (2015), many of the developing countries are rich in minerals and at the same time one of the least developed due to over dependence on one sector as major source of revenue. For rapid development in Nigeria, there is the need to move from the mono-based approach and tap into the huge opportunities available in solid mineral development. The fundamental objective of this study is to predict the effects of economic diversification on solid mineral development in the attainment of sustainable development. Adopting multiple linear regression model, empirical findings are indicative that solid mineral development would be of immense benefit to the diversification of Nigerian economy in the area of employment creation, infrastructural development and improved internally generated revenue. This will however be impossible if the right policies are not in place and vigorously pursued.
\end{abstract}

Keywords: Solid mineral, Solid mineral development, Economic diversification, Sustainable development

JEL Classification: C21, C53, D78, L78, O12, 013, Q01.

\section{Introduction}

According to Dantata (2011), Nigeria is blessed with huge deposits of solid minerals widely distributed across the different geographical zones. As at today, Nigeria is endowed with 44 different mineral types in varying commercial quantities found in more than 450 different locations (MSMD, 2016. Given the enormous deposits of these minerals, developing the solid minerals could serve as a strategy for the rapid development of the Nigerian economy as well as boost revenue generation, create job opportunities and reduce poverty. As noted by, Akonji and Wakili (2013), Edeme, Onoja and Damulak (2018), solid mineral development, holds the key to Nigeria economic diversification because of its ability to stimulate rapid economic growth and a vital tool for employment generation.

Solid minerals are relevant to the economic and social development of many countries. Although contradiction exists when countries and regions with abundance of natural resources specifically nonrenewable resources like minerals and fuels, tend to have less economic growth and worse development outcomes than countries with little natural resources (Akujuru, 2015). Studies such as environmental effect of solid minerals exploitation in Nigeria assert that natural resources abundance particularly mineral resources have adverse effects for economic growth. To support this resource course hypothesis, Sachs and Warner, (1977) affirm in their study that countries with abundant natural resources have tendency to grow slower in their economics than those countries without substantial natural resources, their paper examined the trend for 20-year period of 1970-1990. They concluded that having controlled 
for many variables, mineral resources are found not to be important for economic growth, which implies that there exist a negative relationship between resources abundance and economic growth. In support of this, Przeworski (1991) asserts that this happens as a result of neglect of other economic sectors thereby causing a decrease in the competitiveness of those sectors which contributes to an appreciation of the real exchange rate of the revenue from this sole resource often leading to variability of revenues caused by market swings, mismanagement by government's corrupt and unstable institutions and agencies. Gelb (1988), in particular stresses that, government typically earned most of the rents from natural resources exploration. Others even argue that natural resources abundance inevitably leads to greater corruption and inefficient bureaucracies, or that high rents from natural resources distract government from investing in the ability to produce growth supporting public goods, such as infrastructure.

Edame and Efefiom (2013) notes that natural resource generate a paradox of plenty when they create dependence and damage other tradable sectors and sources of economic growth and development such as human capital and the manufacturing sector. The dismal performance of the non-oil sector in the past two decades leaves little or nothing to be desired. While the oil sector grew between 2011 and 2012 by about $8 \%$, the non-oil sector had a negative growth of $-0.35 \%$ (OECD, 2010), This has been the longstanding trend which made Ogbonna(2013) to note that diversification of the economy away from its heavy reliance on oil revenues and improving the economy's future growth as an important goal, and policies to expand solid mineral revenue and reduce the over dependence on oil export desirable; hence the drive for increased exploitation of the nation's solid mineral sector. The growth of any economic entity is driven by a balanced and effective resource mobilization. Resources are divers in nature with each having its contributory propensities to the overall growth of the economy. No doubt, Nigeria as a country is well endowed in human and natural resources, yet the focus of government since independence has been more on crude oil exploration and exportation to the detriment of other productive economic activities that could bring about the much desired growth. Over the years in Nigeria, solid minerals revenue has accounted for a small proportion of total government revenue. This is because the bulk of revenue needed for development purposes is derived from oil. Crude oil export has continued to account for over $80 \%$ of the total federal government revenue, while the remaining $20 \%$ is contributed by solid mineral sector. For instance, Oil sector share in total revenue was $54.4 \%$ in 1972 against $45.6 \%$ share from solid mineral sector the same year. By 1974 oil share of total revenue had reached $82.1 \%$ while only $17.9 \%$ accrued from solid mineral sector. Following the glut in the world oil prices in the later part of the 1970 s, the oil share in total revenue fell to $61.8 \%$ in 1978 while non oil sector's share rose to $38.2 \%$. And since 1984, the oil sector share in total revenue has continued to rise, though with occasional falls in between periods. By 2006, oil share of total revenue had reached $88.6 \%$ against non oil share of $11.4 \%$. As at 2009 , oil sector share in total revenue stood at $78.8 \%$ while non-oil sector accounted for just $21.3 \%$ of the total revenue (CBN, 2010). This has led the economy to focus on the petroleum sector while ignoring the other sectors as well as the potential revenue that could be generated from them.

Inspite of this, the benefits of solid minerals in the country should not be undermined in the economy. To this end, mining industries have been viewed as key driver of the growth process, especially as lead sectors that engender economic diversification which can lead to higher levels of social and economic well being. But in some countries, especially developing ones, the share of solid mineral contribution to the growth process has been negligible. For rapid development in Nigeria, there is the need to move away from the mono-cultural economy in order to make growth its focal objective. Beside the benefits earlier discussed, Nigeria stands to have better infrastructure and likely reduce poverty, inequality and unemployment from solid mineral development. It is in view of this that paper predicts the effects of economic diversification on solid mineral development in Nigeria. 


\section{Literature Review}

Dutch disease model of 1970 s and 1980 s, have different shades of opinions regarding the reliability of the natural resources in propelling the economic growth of a country. The essence is that emphasis should be placed on manufacturing sector as opposed to the natural resources production which would lead to more robust division of labour and hence to a higher standard of living. Dutch diseases models demonstrated that the existence of sector dominated by natural resources have the tendency of affecting the distribution of employment in the entire economy and equally lead to the pulling of resource in and out of non traded sectors. This sectoral shift can affect long term growth in the economy. Among studies on the impact of mining of the solid minerals is Roderick (2001), who analyzed the effect of mining on economic sustainability, employing mainly qualitative analysis. The findings suggest that through appropriate responses to the challenges of mining and economic development, the benefits of mining can be sustained, even when a mine or a mining community inevitably declines as the ore runs out. Mineral wealth lives on, but in other forms such as in educated and healthy people, efficient and fair social institutions, and man-made physical capital but mining and minerals can be a curse if the challenges are not met.

Olumide, Akongwale and Udefuna (2013) also looked at the non-oil sector and focused on the solid mineral sector using both quantitative and qualitative analysis in showing that the sector has great potentials in contributing greatly to the economy, stating that the sector can stand as a source of job creation and by this eradicate poverty and also help in wiping off problems that are linked with the "enclave" nature of the Nigerian economy through the strengthening of the sector policy and the government creating a conducive atmosphere in order for the private sectors to be in control. In a study on the impact of conflict on mining in Nigeria Adekeye (2010) revealed that there is much more to be gained from the development of mining sector than is usually organized and there is very much to lose from the non-development of the sector. Agba (2007) in his study on economic analysis of natural resources sustainability for the mining sector component in Nigeria, employing both qualitative and quantitative (descriptive) analysis, the study revealed that Nigeria stands to benefit from the development of solid minerals sector and concluded that the government must provide enabling environment for the private sector investment in mining. Akongwale (2013) employed both qualitative and quantitative approach to shows that solid mineral sector in Nigeria has the potential to contribute immensely to the economy of Nigeria. Specifically, the study reveals that the development of the solid mineral sector could help to combat poverty in Nigeria via job creation; especially, given its forward linkage with other sectors of the economy. Most importantly, it could help alleviate some of the problems associated with enclave nature of the Nigerian economy that has for too long being vulnerable to fluctuations in global oil prices. However, as argued, the realization of these potentials need the strengthening of Nigeria's existing solid mineral development policy and creation of an enabling environment by the government for the private sector to take the lead in the sector. In agreement with this, Sada (2012) opine that more useful adjustment should be made to promote effectiveness, liability and also the reduction or elimination of corruption.

Mineral development can lead to the development of various infrastructural facilities. For instance, improvement of mine to extract mineral resource sometimes needs the creation of roads, buildings, railways, pipelines, power lines and communication facilities. Although, it has be acknowledged that mines have made considerable infrastructure and social investments in some communities, it have been argued the enclave character of mining in developing countries restricts investments that support mineral extraction (Breckenridge, 2008; Matti, 2010).

\section{Methodology}

The variable, achieving economic diversification through sustainable solid mineral was regressed using the forced entry and stepwise regression against some predictors. Following the works of Ayeni, (2013), this study adopts a multi-variate analysis using multiple regression model specified as: 


$$
\boldsymbol{g}=b_{o}+\varphi_{1} X_{t}+\varphi_{2} X_{2}+\varphi_{3} X_{3} \ldots \varphi_{n X n}+\mu_{t}
$$

where $\boldsymbol{g}=$ dependent variable, $\varphi_{o}=$ intercept, $\beta=$ slope, $\mathrm{X}=$ explanatory variable

Equation (1) is specified to check for strength, direction of relationships, significance and also to determine relationship. A multiple regression equation for predicting $\boldsymbol{g}$ is expressed as:

$$
\boldsymbol{g}_{p}=b_{o}+\varphi_{1} X_{t}+\varphi_{2} X_{2}+\varphi_{3} X_{s} \ldots \varphi_{n X n}+\mu_{t}[I F R, I G R, G V P, S M D]
$$

where $\boldsymbol{g}_{p}$ is economic potential of solid mineral development

In the forced entry regression, all the independent variables were entered simultaneously into the model to determine those that are significant to the model. Some variables were regressed against the economic potentials of solid mineral development using forced entry in checking the relationships. The variables are: infrastructure and solid mineral development, contribution of solid mineral to internally generated revenue and policy strategies for solid mineral development.

\section{Results and Discussion}

Results from the Forced entry method in Table 1 shows $F=14.0872$, R Square $=0.6901$ and indicates that only four predictor variables significantly explain the residual variation in economic diversification. The variables are infrastructural development, opportunities in solid mineral development, internally generated revenue and government policy.

Table 1.

Regression Result

\begin{tabular}{|l|l|l|l|l|}
\hline Variables & Coefficient & Std. Error & t-Statistic & Prob \\
\hline SMD & 0.7188 & 0.3194 & 2.2506 & 0.0000 \\
\hline INFD & 0.0018 & 0.0026 & 0.6792 & 0.2895 \\
\hline GVP & 0.1412 & 0.0902 & 1.5656 & 0.0000 \\
\hline INGR & 0.2086 & 0.1572 & 1.3269 & 0.0000 \\
\hline f-statistics & 14.0874 & & & 0.0000 \\
\hline $\mathbf{R}^{2}$ & 0.6901 & & \\
\hline
\end{tabular}

Source: Authors Computation

Furthermore, the Stepwise regression was employed with solid mineral development as the dependent variable and opportunities in the development of solid minerals, infrastructural development, contribution to internally generated revenue and government policies as the predictor variables. These were entered into the model in turn according to the standardized coefficient.

Table 2.

Stepwise Regression Result

\begin{tabular}{|l|l|l|l|l|}
\hline Variables & Coefficient & Std. Error & t-Statistic & Prob \\
\hline SMD & 1.0084 & 0.2314 & 2.8340 & 0.0000 \\
\hline INFD & 0.1270 & 0.0900 & 1.0780 & 0.2895 \\
\hline GVP & 0.0367 & 0.5883 & 3.0313 & 0.3000 \\
\hline INGR & 0.4961 & 1.0254 & 1.4538 & 0.0000 \\
\hline Constant & 2.5012 & 0.6432 & 2.0921 & 0.5421 \\
\hline f-statistic & 30.8200 & & & 0.0000 \\
\hline $\mathbf{R}^{\mathbf{2}}$ & 0.5439 & & \\
\hline
\end{tabular}

Source: Authors Computation 
From the result in Table 2, there is evidence that opportunities in solid mineral development has the highest coefficient of 1.0084 and contributes the most to the model with absolute significance. This was followed by contribution to internally generated revenue with a coefficient of 0.7961 , infrastructural development (0.1270) and government policy with a value of 0.0367 .

In predicting the potential to achieving economic diversification through solid mineral development, the equation for best line of fit was substituted as:

$$
\boldsymbol{g}_{p}=2.5012+1.0084(\mathrm{SMD})+0.1270(\mathrm{IFDR})+0.0367(\mathrm{GVP})+0.4961(\mathrm{IGR})
$$

Evidence from the result depicts that economic potential in solid mineral development contribute the most to the model, with correlation coefficient of 0.632. Intuitively, holding all other factors constant, Nigeria will attain 51 percent economic diversification if solid mineral sector is fully harnessed, Considering the huge deposit and potentials in solid minerals that are abound in Nigeria, the country is at a veritable position of harnessing solid mineral for employment creation, poverty reduction and enhancing the revenue base of the country. Other benefits include infrastructural development, economic growth, competitive value, social integration among others. The correlation coefficient of internally generated revenue with economic diversification is 0.554 and solid mineral development depicts a co-variation and association between the two. The regression coefficient of 0.198 is an indication that if solid mineral sector is fully harnessed, internally generated revenue will improve by about22.5 percent, provided the effects of other variable remain constant. A major policy implication from this finding is that solid mineral can be explored as an additional source of internally generated revenue by tapping into the numerous solid mineral deposits in the country. Fortunately enough, all regions or states in Nigeria are relatively endowed with solid mineral resources which they can harness as alternative source of revenue to supplement allocations from the Federal government. In this regard, the numerous solid mineral deposits all over the country should be focused on and developed appropriately to serve as additional internally generated revenue.

Infrastructural development contribution to solid mineral development ranked third with a correlation coefficient of 0.554 . This implied that infrastructural development has a great role to play in enhancing the economic potential of solid development. In specific term, improvement in infrastructure by 1 percent leads to about 16 percent economic diversification attainment. The provision of basic infrastructure is a pre-requisite towards attaining economic growth. Infrastructures will support the tourists' needs and encourage investment. Thus without the necessary tourism infrastructure being put in place, tourism in Nigeria would not progress. In essence, adequate infrastructures need to be provided for all the states to benefit from tourism. This will include, road, landscaping elements, recreational facilities, constant electricity supply, decent hotel accommodation, water, efficient transportation, solid waste disposal and effective communication. With a correlation of 0.036, government policies also has a role to play in increasing potentials in solid mineral development. The regression coefficient is 0.03 in absolute terms implies that favourable policies will engender solid mineral development by about of 0.3 percent while the effects of other variables are held constant.

\section{Conclusion}

The study has elaborated on the need for the Nigerian economy to be diversified in order to improve other sources of revenue. Using the multiple regression model, the study demonstrated several roles solid mineral development could play if given its pride of place in the country. These include infrastructural development, a great source of revenue generation, and also the employment creation and poverty reduction. This will however be achievable if the right policies are in place and vigorously pursued. 


\section{References}

Akonji, D.A \& Wakili, A. M. (2013). Solid mineral resources: Alternative source of revenue for the Nigerian economy. Journal of Emerging Trends in Economics \& Management Sciences, 4 (5): 487-492.

Akujuru, C.A. (2015). Revenue allocation in Nigeria and the dependency on oil revenue: The need for alternative solutions. Global Journal of Arts Humanities \& Social Sciences, 3(2): 19-36.

Ameh, E. (2009). Oil price slump and imperative of diversifying the economy. Business Day $\quad$ Online 12 January, Available from http://www.businessonline.com

Ayeni, D, A. (2013). Predicting the effects of economic diversification on sustainable tourism development in Nigeria. American Journal of Tourism Management, 2(1): 15-21. Available at: $10.5923 / \mathrm{j}$. tourism.20130201.02.

Ayodele, O. S., Akongwale, S \& Nnadozie, U. P (2013). Economic diversification in $\quad$ Nigeria: Any role for solid mineral development? Mediterranean Journal of Social $\quad$ Science, $4 \quad$ (4). Available at: doi.org/10.5901/mjss.2013.v4n691.

Edame, G.E. \& Efefiom, E.C (2013). The trend analysis of oil revenue and oil export in Nigeria. Journal of Business and Management, 10(3): 1-8.

Edeme, R. K., T. C. Onoja \& Damulak. D. D. (2018). Attaining sustainable growth in Nigeria: Any role for solid mineral development? Academic Journal of Economic Studies, 4 (1): 105-110.

Eyre, J. M. \& Agba, A. V. (2007). An economic analysis of natural resources sustainability for the mining sector component-Nigeria. Available at: www.wardell-armstrong.com .

Herb, M. (2009). A Nation of Bureaucrats: Political participation and economic diversification in Kuwait and the United Arab Emirates. International Journal of Middle East Studies, $\quad$ 41: 375-395.

Hlavová, I. N (2015). The impact of mineral resources on economic growth. International Journal of Arts \& Commerce, 4 (6): 100-110.

Ogbonna I. C, Uwajumogu, N. R., Chijioke G. Agu S.V. (2013). Economic globalization: Its impact on the growth of non-oil supply in Nigeria. Journal of Economics \& Sustainable Development, 4(7).

Olalekan, D. O, N. O, Afees \& Ayodele, A. S. (2016). An empirical analysis of the contribution of mining sector to economic development in Nigeria. Khazar Journal of Humanities \& Social Sciences, 19 (1): 88-106.

Olumide, S. A., Akongwale, S. \& Udefuna, P. N. (2013). Economic diversification in Nigeria: Any Role for Solid Mineral Development?, MCSER-CEMAS, Sapienza University of Rome, 4 (6): 691.

Przeworski, A. (1991). Democracy and the market: Political and economic reforms in Eastern Europe and Latin America, Studies in Rationality and Social Change, Cambridge. Cambridge University Press.

Roderick G. E. (2001). Mining and Economic Sustainability: National Economies and Local Communities, Division of Economics and Business, Colorado School of Mines, US.

Sachs, J. D. \& Warner, A. M. (1997). National resources and economic growth, Discussion Paper, Harvard Institute of International Development.

Suberu O. J., Ajala, O. A., Akande M. O \& Olure-Bank, A. (2015). Diversification of the Nigerian economy towards a sustainable and economic development. International Journal of Economics, Finance \& Management Sciences, 3 (2): 107-114, doi: 10.11648/j.ijefm.20150302.15.

UNEP (2011). Towards a green economy: Pathways to sustainable development and poverty eradication- a synthesis for policy makers. Paris: United Nations Environment Programs-UNEP. 